\title{
Conceptualizing the Co-Existence of Formal and Informal Institutions Within Planning
}

\author{
Hazem Abu-Orf \\ Faculty of Applied Engineering and Urban Planning, University of Palestine, Gaza, Palestine
}

\section{Email address:}

h.orof@up.edu.ps

\section{To cite this article:}

Hazem Abu-Orf. Conceptualizing the Co-Existence of Formal and Informal Institutions Within Planning. Urban and Regional Planning. Vol. 3, No. 3, 2018, pp. 80-91. doi: 10.11648/j.urp.20180303.11

Received: September 8, 2018; Accepted: October 4, 2018; Published: October 24, 2018

\begin{abstract}
The background to this study is addressing how formal and informal institutions might intersect in planning. This article has at its aim addressing not only the effects that formal and/or informal institutions have but also how both shape each other. In fulfilling this aim, analysis in this study adopts qualitative research methods, including qualitative interviewing, direct observation and archival records, which are applied to the Nicosia Master Plan that is considered in this study as a particular case study because it arguably helps this study to fulfill its aims. The perspective of formal/informal 'dialectics', marked by a 'mutual-shaping' exercise, is applied to this case study. Its application reveals several arguments as follow. First, formal institutions are found in this study to be blocked from mobilizing any development, however, remain the key determinant. The second argument concerns informal institutions that have been found to adopt strategies capable of mobilizing development, nevertheless, these strategies could not obviate the central role of formal institutions. Thirdly, formal institutions formalize informal institutions by 'absorbing' the latter into their hierarchy while equally denying any degree of autonomy, nor a role assigned, to informal institutions. Altogether, the findings revealed in this study stress the importance of the political and economic contexts of power that are key to how the formal/informal 'dialectics' occur.
\end{abstract}

Keywords: 'Mutual-shaping', Dialectics of Formal/Informal Institutions, New Formality, Formal/Informal Configurations

\section{Introduction}

This study has at its aims examining the interplay of formal and informal institutions in planning. In planning theory, following new institutionalist debates in sociology, economics and political science, much attention has been paid to institutions, both formal (like norms and roles) and informal (like values, conventions and codes of behavior) institutions. Institutional change has thus been a central theme in the debates in planning theory since the early nineties (for example, [1-4]). The concern in planning literature has been with building institutional capacity by agents unfolding their practices so that they could adapt changes, within collaborative practices, in an attempt to break through institutional pathways and their structural forces $([3,5])$.

Although methodological and theoretical differences remain in all variants of institutionslism - for example, rotational choice, historical, sociological and discursive institutionalism - to conceptualize stability, change and casual processes within social and economic systems, a consensus emerges among new institutionalist which addresses the questions of what institutions are and how to articulate them, in addition to understanding the centrality of rules and norms. "[N]early all definitions assume that they are relatively enduring of features of political and social life (rules, norms and procedures) that structure behavior and cannot be changed easily or instantaneously" [6].

It is widely acknowledged that not only the formal aspects - the formal "rules of the game" and their enforcement - are paramount but the informal aspects of institutions - the norms, rules and practices -often less visible or even passing unnoticed - are also crucial [7]. Scholars are now seeking to reveal the hidden aspect of institutions, rising questions for addressing concerned with how can/do informal institutions either sabotage or facilitate a change. And, when they have a crucial role in institutional change, should changing informal institutions gain a more important focus? Or, are they more insurmountable than formal institutions, thereby calling for varying change strategies? 
Central to new institutional analysis is an analytic distinction between formal and informal institutions, ideas and structures, on one hand. For new institutionalists, formal structures, laws and rules are different from informal norms or conventions, and both are equally treated as being different from ideas and macro-structural variables $[8,9,10]$. On the other, whilst the existence of informal institutions is well recognized, yet it seems to exist a considerable doubt about how such institutions arise and also about the nature that characterizes the relationship between formal and informal institutions $[11,12,13]$. Not surprisingly, therefore, the new institutional literature tends to be 'polity-centered'; the debate remains anchored in governing institutions and formalized rules, together with the informal conventions related to them. In essence, formal institutions are a central theme as the subject representing a change, while leaving informal institutions aside which are labeled with being problematic [14], a source of corruption [15], or with resistance, rather than being an option for mobilizing a change. While some scholars remain skeptical, many have argued that, in addition to informal institutions' importance, such institutions are apparently durable and not always hangover of 'tradition' [16]. As a result, a more nuanced approach of informal institutions and their intersection with the formal has accentuated to overcome the predominantly negative meanings attached to informal institutions [17-18].

Indeed, scholars have started to investigate informal institutions to help them insight the interaction between the formal and informal. Several typologies marking the different roles played by informal institutions in association with formal ones are evident. Collectively, informal institutions might have positive and/or negative effects on the strength and functioning of formal institutions. Informal institutions might be viewed for example as being complementary, substantive, or competing with formal institutions [17]. Another example, informal institutions are seen from the perspective of being able to compete with, exist in parallel to, or to coordinate formal institutions [19]. A further example is transitional regimes of Eastern Central Europe where informal institutions could replace, undermine, support, or strengthen formal institutions irrespective of strength of the formal institutions they co-exist with [20]. How informal institutions act in completing, complementing, coordinating or distorting ways is yet unclear. One may therefore argue that although the literature concerned with informal institutions appears to be yet underdeveloped, its typologies share a common ground, that is; the central theme underpinning such typologies is the need to address the question of how formal and informal institutions interact.

In response, analysis in this study addresses the above question by adopting the formal/informal dialectics. In this respect, formal planning on its own is not feasible, or, informal planning alone will be 'vulnerable' [21]. Given the significance of informality in planning, planners are encouraged to develop a framework that ties formality and informality [21]. The perspective of formal/informal dialectics does so and investigates how state planning system and informal institutions shape each other in their coexistence. A 'mutual shaping' perspective, or, a 'mutual adaptation in evolving governance', emerges and this perspective is characterized by a 'continuous interpretation'. This is because a swap of rules and roles mark this perspective appearing in the form of being 'exploited, twisted' or 'altered' and leading to formal/informal 'configuration', instead of opposed formal/informal relation.

The perspective of formal/informal dialectics has an interesting premise; however, its analysis lacks empirical backing. The perspective also remains purely hypothetical, assuming, rather than explaining, the relation of formal/informal institutions in planning. A further problem is this perspective's ignorance to planning context. Institutions evolve differently from one part of the world to another. Therefore, scholars (for examples, [19, 20, 22, 23]) investigate the emergence and adaptation of informal institutions in divergent contexts, looking at the reasons for change, different interactions and outcomes in varying contexts. Important gaps in knowledge thus emerge in this respect. Analysis in this study attempts to fill in these gaps by putting flesh on the perspective of formal/informal dialectics through fine tuning situated within a case study of Nicosia Master Plan (Cyprus).

The organization of this article is as follow. Its analysis reviews the literature on institutionalism concerned with the interaction of formal and informal institutions, followed by clarifying the perspective of formal/informal dialectics, together with the latter's key concepts. Before presenting the conclusions, analysis in this study applies the concepts of formal/informal dialects to the Nicosia Master Plan.

\section{Formal/Informal Institutions in Planning}

\subsection{The Interplay of Formal and Informal Institutions}

Since there are many assumptions about how to define institutions, analysis in this study confines its analysis to accounts already published in sociology and political sciences. In sociology, institutions exist when 'general normative patterns of social action' take place within a society [24]. Thus, institutions imply a cultural rule of conduct. Institutions are in this respect reproduced [25] and their meaning evolves due to being reproduced in continually changing surroundings [26].

Conversely, the sociologist notion of organization refers to a fixed pattern that would strengthen when conducting functional or coordinating activities. Accordingly, organizations are in practice oriented to special tasks equipped with specific goals and outcomes, and these have often a particular time frame [27]: organizations are accordingly much anchored in operational practices. Conversely, institutions point to values that are applied more broadly. One result is institutions' structure that will vary from that of organizations. Another result relates to the codes of behavior applicable in a more general sense, as these 
represent general rules. Following [14] and [28], institutions are interpreted through rules, or norms, which effect individuals and human behavior. In contrast, organizations embody the social structures of agency - they are purposeful. The distinction of institutions and organizations marks the roles of formal and informal institutions as being other than merely organizational forms, even in a broader context of an organization than formally constituted system of actors.

Despite new institutional behavior scoring success concerning the existence of the firm as an organizational form [13], institutional behavior remains poorly interpreted ignoring how informal institutions shape interactions [12]. The problem is not a concern with a lack of recognition of the informal [29]. Rather, a curious inability of new institutional economics poses a serious deficiency to get to grips with informal institutions. Therefore, it is suggested [14] to move away from a focus centered on institutions as determinants of economic performance, grounded in efficiency, towards institutions that emerge through negotiations governed by power relations: "Institutions are not necessarily or even usually created to be socially efficient; rather they or at least the formal rules, are created to serve the interests of those with the bargaining power to devise new rules".

Before proceeding further, it is useful to shed light on North's perspective of institutional change. Accordingly, formal and informal institutions are treated differently, and the perspective underlies the inertial nature of the latter. Institutions are accordingly seen as constraints [14]: "informal constraints that are culturally derived will not change immediately in reaction to changes in the formal rules," leading to a "tension between altered formal rules and the persisting informal constraints". Whilst changes are made to formal rules, and enforced, by the state, informal ones are closely associated with cultural inheritance, adding that "path-dependence can and will produce a wide variety of patterns of development, depending on the cultural heritage and specific historical experience of [each] country" [30]. Another pitfall is the lack of 'enforcement' of formal rules: "Economies that adopt the formal rules of another economy will have very different performance", primarily due to "different informal norms and enforcement" remarks [31].

Proponents of North's perspective regard informal rules as a negative legacy of the past. They recognize that the right, or, 'adaptively' efficient set of enforcement associated with the informal rules, is not acknowledged in the state of institutional economics. This is because North's perspective focuses on formal institutions while ignoring informal institutions (equated with cultural legacies), largely because the latter is regarded for North perspective as a hindrance to a progressive change.

Therefore, many scholars have extended the new institutionalist view to explore the interaction of formal and informal rules. One scholar [32] goes for 'interaction thesis', noting, for example, that formal institutions suppress, however have less impact on amending informal institutions. Another scholar [33] characterizes the interaction between formal and informal rules by resilience, scoring harmony between both rules and observes that informal rules could slow down the positive impact, and equally limit the negative effects, of the new formal rules. A third scholar [34] draws on congruent norms tied to formal rules, and mutually reinforcing, and on opposition (informal) norms determined by economic performance. A further scholar [35] suggest overlap and spheres of interaction between formal rules (external institutions sanctioned by the state) and informal rules (internal institutions agreed by members of the community) which their co-existence shows a neutral, complementary, substantive, and conflicting relation. It is added [36], internal institutions would progress more slowly than external ones would do, and this is because the former are not subject to deliberate choice mechanism.

The above approaches view the interaction of formal and informal rules from a historical change. Yet, a one-sided focus on formal institutions remains. While being recognized informal institutions are yet conceived as a problem to be solved and traceable to effort of the formal arrangement. Therefore, while the majority of institutions are informal and seeks a long-term effect on social and economic trajectories, no adequate explanations are offered addressing how informal institutions arise or change [11]. Normative stances flagged by 'good-rules' emerge suggesting a formality- or informality-centered harmony between formal/informal institutions, together with an emphasis on a one-sided assessment of efficiency and performance, that may well disrupt the institutional analysis.

Not surprisingly, therefore, some scholars (for example, [17-18]) turn to informal institutions, and view institutions as "rules and procedures (both formal and informal) the structure social interaction by constraining and enabling actors' behavior" [17]. They articulate informal institutions as constituting the "socially shared rules, usually unwritten, that are created, communicated and enforced outside of officially sanctioned channels" in opposition to formal institutions that are "rules and procedures that are created, communicated and enforced through channels widely accepted as officials."

Other scholars, see [19], have made an attempt to address how informal rules co-exist with formal ones. They point to three functions of informal institutions in developed countries: 1) they fill gaps that formal institution might not be able to fulfill; 2) they coordinate overlapping or clashing formal institutions and 3) they operate parallel to the formal planning system. Informality is [often] configured as the other (a residue) to formal institutions: what cannot be dealt with using formal rules is left to informal institutions [37]. Similarly, informal institutions compete with, or be congruent with, formal institutions [38].

Rather than viewing informal institutions as a pre-existing structure, or as the other, scholars investigate informal institutions within different planning contexts. A new insight is added which states that formal and informal institutions influence each other. in East Central Europe's planning context [20], the interaction of formal and informal 
institutions reveals that this interaction has its impact on the types of formal institutions that accentuate and also on what kinds of informal institutions are sustained. In China [24], new informal institutions emerge as a result to formal institutions while being key to 'endogenous' institutional change. "Adaptive" institutional change is accordingly a creative approach because it harmonizes the needs for varying, or incompatible, formal institutions. Formal institutions change due to violation of, or dissatisfaction with, informal institutions [19]. As a result, local actors initiate actions on the ground to reinforce changes to formal rules, thereby mitigating the problems. The rise to a change occurred at the formal/informal intersection varies in accord to whether informal institutions are completing, in parallel or coordinating formal institutions [19]. A change to formal rules thus fails because those completing informal institutions necessary to fill gaps, or resolve ambiguities, to formal institutions are absent.

An interesting finding to emerge, in this subsection, is that informal institutions could both circumscribe and boost the changes to be made to formal rules. Or, informal institutions are capable of disrupting a change to formal rules rather than stymie it [36]. The review citied here shows that the nature of formal/informal interaction is complex, making it difficult to suggest straightforward assumptions.

\subsection{Formal/Informal Dialectics}

The perspective of formal/informal dialectics suggests that new institutionalism in planning literature hinges on instrumentalist perspective bringing to the fore prescriptions that tend to be 'overly simplistic' or 'engineeristic' [21]. Moreover, as the previous subsection shows, new institutionalism literature focuses on formal institutions, or investigates the effects of informal institutions to formal rules, while investigations lack addressing how formal and informal institutions in their co-existence are embedded in a broad set. The perspective of formal/informal dialectics stems the problem and turns to the dialectics of formality and informality in planning using insights from transition studies, new-institutional economists and social systems [21]. The perspective brings to the fore a dialectical view because it addresses how formal and informal institutions in planning processes not only have their impact but rather shape each other [21]. It is added that the perspective calls for a formal/informal 'configuration' instead of opposed relations [21], because a particular set of formal/informal institutions has certain impact. Before proceeding further it deems useful to outline the notion of dialectics.

Dialectics have been known in the philosophy for debating issues using confrontation, or as synonym of 'logics' (the process of wording, counting or thinking about). '[D]ialectics' are conceived as a central theme in constructing a logical process to weave a reality based on the process of contradicting theses [38]. On the contrary, Hegel's view of dialectics [38] identifies the system of Plato, striving to arrive at developing contents. Such a view would not therefore lead to swapping contrasts, rather to construct unity. For Hegel's view, logics could be varied, ranging from abstractive (sensible), dialectical (negatively sensible) and notional (positively sensible). As such, dialectics note the destruction of certain terms and their transfer into oppose each other concepts.

The perspective of formal/informal dialectics [21] takes the notion of dialectics further in planning and suggests that formal institutions evolve due to adaptation to informal rules. Formal institutions are commonly associated with written rules and state - provided mechanisms. Formal institutions also point to rules that are either forgotten, not communicated within the society or not considered as rules, however, sanctioned by the community. In such cases, The perspective of formal/informal dialectics calls for 'dead institutions', implying that the role of institutions could not be taken as a coordination tool. Formal institutions, on the contrary, could be taken as real. A three-poled concept comprised of formal, informal and 'dead institutions' emerges where roles are reserved or revived. 'New informalities' emerge through 'metarules': rules to apply, choose, reinforce, or diminish other rules. Such rules also provide the option for formal institutions to 'die', however, the previous formality makes possibilities to revive them.

The perspective of formal/informal dialectics notes the evolutionary feature of institutional change. Accordingly, a 'mutual shaping' of formal/informal institutions, or a 'mutual adaptation', occurs in 'evolving governance'. Institutions evolve when swapping rules, namely through 'metarules'. Remarkably, formal and informal institutions do not cease to evolve, even when reviving the roles. 'Dead institutions', once being remembered or reinterpreted, could be revived, restarting their evolution as before, either formal or informal institutions. Yet, how formal institutions affect informal rules within a 'mutual shaping' perspective appears to be absent. Besides, the perspective of formal/informal dialectics assumes, rather than explains, how a 'mutual shaping' occurs.

Before proceeding in the next section with the case study analysis applying the perspective of formal/informal dialectics, the next subsection clarifies this perspective's conceptual frame in planning: these include plans \& planners, the role played by organization and the issue of participation.

\subsection{The Key Concepts in Planning from the Formal/Informal Dialectics}

(1) The role of Plans and Planners

Social, economic, political or ecological contexts directly influence the way planners plan [21,39]. A plan, viewed as a new formal institution, is embodied in these contexts and the many impacts it has stem from the formal/informal dialectics situated in each context. A plan might be reinterpreted, utilized differently, legally impaired, politically marginalized, and economically or ecologically ratified. In such cases, the plan's impact is minimal. A plan poses a threat to 'others', represents a 'potential resource' and could be utilized as 'a weapon'. Plans are accordingly adopted as tools in 'powergames', taking into account the strategic contexts. However, 
how a plan does so remains unexplained in the perspective of formal/informal dialectics.

The perspective of formal/informal dialectics suggests 'formalizing an institution' that has 'unforeseen effects'. Two examples are offered to illustrate such effects. The first concerns when plan formally loses power, however, the inherent principles or co-ordination tools remain in place. In contrast, the second example concerns informal coordination tools that are formalized through turning their informal networks/associations into organizations and also through turning their unwritten rules into planning laws and policies. As a result, the originally adopted coordinative tools will be lost. In addition, formalization has at its heart integrating the other into its political structure, together with using the method of 'absorption of tradition into law'. Consequently, formalization jeopardizes the originally integrated coordinative mechanisms.

A plan, or as the perspective conceptualizes it as 'paper plans', is viewed as formal or 'dead institutions', depending upon how such a plan is interpreted within a particular context. Three functions [21] to 'paper plans' are accordingly suggested. These include paying a 'lip service' or 'maintaining a façade' of the formal coordination to fit others' arrangements. Other functions include: suppressing the informal arrangements, acting as 'alibi' for informal institutions, or posing a threat to the latter institutions. 'Dead formalities' are back on track which can be refreshed at any intervals due to planning being unpredictable. Not surprisingly to argue [21] that the co-foundation effects associated with formal/ informal institutions are not classified easily.

Nevertheless, three scenarios are suggested [21] to the functioning of new formality. One concerns a 'fragile trust' that overwhelms the new formality, leading to weakening the latter's effectiveness in coordinating divergent interests. The other scenario is a reproduction of the already established power structure through the plans and policies that emerge as a result of deliberations. The last scenario concerns new formality that its notion functions as a 'façade' to legalize the interests of those at stake, thereby enabling their benefits. What unite the three scenarios are the formal/informal dialectics [21] that determine how the new formality might function.

(2) The role of organizations

New formal institutions emerge due to the rise of organizations. Their emergence is backed by state institutions and shows that their laws are documented, implying that informal institutions become less important and is accompanied by formal/informal institutional thumbnail characterized by multiple forms of coordination and diverse transactions laying the departure for rather complex formal/informal dialectics.

It is added [21] that the rise of new formal institutions (for example, laws or plans) occurs due to 'reinterpretation of these institutions within different organization', while it remains uncertain whether organizations return to previous informal arrangements. Such interpretations are never 'predictable'. This is because the key to organizations lies in oppositional effects [21], which result in smooth coordination, or equally, in vague coordination. Accordingly, organizations play the role of arranging assignments while conversely making it hard to understand how institutions are interpreted or processed. The dialectics of formal/informal institutions are at stake, where the effects resulting from one institution on the other are numerous.

(3) 'Participation' or 'representation'

Is it feasible to override issues arising from institutional arrangement by adopting strategies inherent in participatory approaches? [21] A straightforward response is not the case. To explain, one example concerns the inclusion of more participants within planning discourse which leads to 'visibility' of the ongoing institutional matrix [21]. This is true for some planning cases. For other cases, participation results in fostering formal/informal configuration, which might be interpreted as either 'unfair' or 'ineffective'[21]. Another example concerns planning discourse that empowers particular organizations that have less in common with the public interests, leading to marginalizing the newly evolved institutions. A new form of planning discourse accentuates [21] which is 1) less determined by 'checks' and/or 'balances' and 2) steadily grow up in many communities following 'representative democracies'.

Notably, the 'participatory structure' points to a context, where in practice it is naïve to suggest that a planning discourse is featured with open discussions; honest or 'clean' participants while being subtracted from strategic shaping. Also, the 'participatory structure', as a new formal institution, is each time reinterpreted, and is determined by similar conditions that have faced previous formal institutions. It is arguably difficult to predict how the new formality and its 'participatory structure' would proceed.

\section{The Nicosia Master Plan}

\subsection{Research Methodology}

The empirical discussion, that follows, is based on two separate research visits that were made to both parts of Nicosia, namely in 2002 and 2010. The decision to do so is associated with Nicosia's violent context (see next subsection on Nicosia's background). Another example showing how context directly affects the methodology chosen for this study's data collection is interviewees' fear of others; here the author is conceived as stranger or outsider. The research method adopted for this study is therefore a methodological triangulation of qualitative methods to enhance the inner validity of the data collected in each visit: 1) documentary analysis (including Nicosia Master Plan's (NMP) reports and those published by both formal institutions, existed northern and southern the UN Buffer Zone); 2) media survey; and 3) qualitative interviewing. Twenty-four interviews were in total conducted in a semi-structured fashion, largely with open-ended questions.

Purposeful sampling (the interviewees' selection 
procedure) was employed for this study. The selection has ceased, when 'saturation' (no new themes emerged) has been reached. Notably, interviewees have been neither entirely homogenous nor necessarily mutually exclusive. Rather, they constitute a reasonable cross-section of numerous professions of the NMP 'team' - architects, planners, sociologists, economists and politicians. Most interviews have lasted up to two hours each, and their records have been documented shortly afterwards, guided by the notes taken while interviewing.

\subsection{Background to Nicosia's Division and its Master Plan}

Nicosia's division, in effect since 1956, became permanent with the Turkish invasion of Cypriot island in 1974. This occurred after a right wing military junta government in Greece staged a coup in Cyprus and overthrew the leader Archbishop Makarios to install a pro-Greek puppet regime. Nicos Sampson, an EOKA (the National Organization of Cypriot fighters) regarded as an ardent enemy of the Turks and the chief of private militia, was installed as new president. Turkey reacted by invading Cyprus, occupying $37 \%$ of the island, coming up to the 'Green Line', which physically divides the walled city of Nicosia into half. In 1983, the Turkish Cypriot president, Rauf Denktaş, declared this territory a sovereign republic, the TRNC, which has never been internationally recognized, other than Turkey.

Ever since 1964, in the longest peace-keeping mission in history, the United Nations has retained control of the Buffer Zone, which runs through Nicosia's historic center. International agencies, such as UNDP and USAID, have been funding a number of programs: such as the NMP, in 1979, a bi-communal project aimed at reintegrating the city's twourban fabrics, and de-mining of this zone.

The NMP has also at its aims representing interests of the two major ethnic communities: namely Greek- and Turkish Cypriots. The NMP has been developed in two phases. The first explores the context of division. This has helped the NMP adopting a style of discourse that enabled a diverse range of views to be heard. The 'representatives' (members of the NMP's team), as named by interviewees, have been able to generate trust and identify issues of common concern. A comprehensive planning policy has followed by 1984 . Phase II, 1985-1987, has implemented this policy using specific area schemes, to be chosen within Nicosia's WalledCity (Figure one).

Both phases aim at overriding issues of recognizing 'others' territories, strengthening the argument that the NMP is 'humanitarian' in nature. For example, the 'representatives' political legacies, or their institutional affiliations, are detached on entering the NMP discourses. Another example, the NMP is re-packaged as primarily addressing technical matters. The political circumstances have been debated at the 'top-level' discourses (Interview, former Turkish Cypriot mayor). The key is to avoid the NMP becoming involved in issues of the territorial division of Cyprus. As will be illustrated in the subsections that follow, this has been a promising ideal.

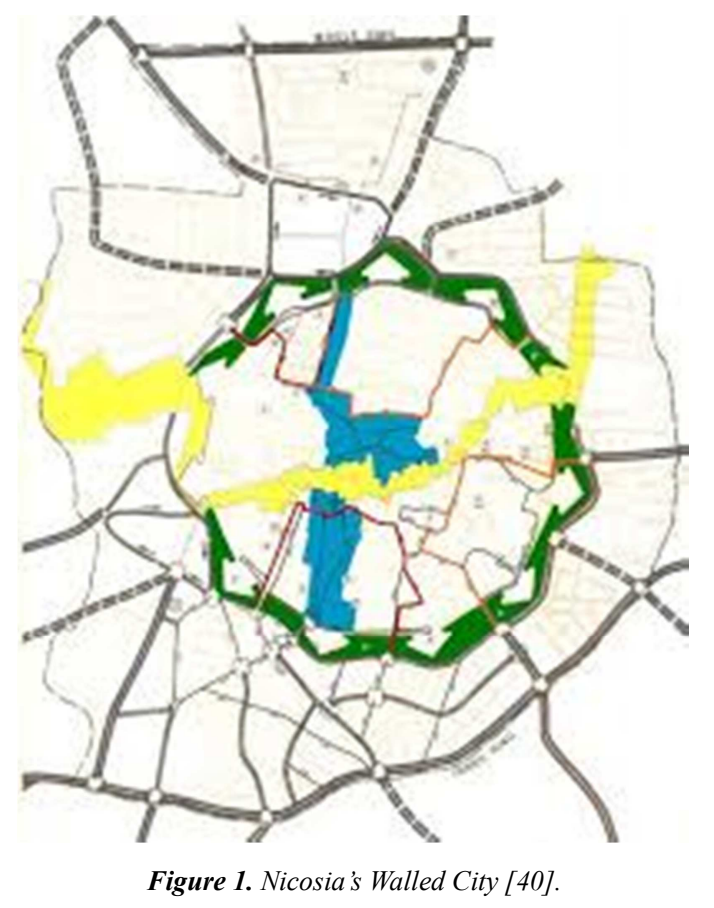

\subsection{The NMP Formal/Informal Dialectics}

This section investigates not only the effects of formal and informal institutions in planning but also how they shape each other. Analysis of this study suggests a strategic shaping arising from the economic and political contexts in which the NMP is located. These contexts embody power relations. A 'mutual shaping' is evident in these relations. The NMP has been accordingly overshadowed by politics of not recognition, which precludes its planning process. As previously explained, the NMP has adopted certain strategies to, temporarily, by-pass these politics enabling a joint project in planning to emerge.

However, the 'representatives' could not be abstracted from their institutional legacies on entering the NMP discourses. Interviewees interpret their assumption by arguing that the 'representatives' are obliged to consult each institution before handing a decision. A Greek Cypriot interviewee (an architect and senior NMP member) suggests that the 'representatives' have had less power in the institutional hierarchy, and reveals that they have had to await final approvals of their Municipality: 'a big difficulty which we [the NMP 'team'] are facing is the nature of the joint team as a dependent team [...]'.

Turkish Cypriot interviewees view their 'representatives' as part of an institutional 'matrix'. Their 'representatives' have been 'clothed' in their formal institutions' concern by representing the latter's interests. As Turkish Cypriot interviewees report, Turkish Cypriot Municipality claims that it is legitimate right to handle planning permits. The Municipality has therefore employed most Turkish Cypriot 'representatives' since 1990. The issue of 'fear' accentuates, representing a threat of 'losing jobs' to Turkish Cypriot 'representatives' when the latter opposing the Municipality's policy of a 'separate coexistence' based on a satisfactory 'status-quo'. 
A further example to strategic shaping lies in either side's formal institution exercising legitimacy over the NMP. Each Cypriot formal institution has had to agree upon whom form its territory could participate (Interview, Turkish Cypriot planner and former NMP 'team leader'). Greek Cypriot formal institutions permit their 'representatives' to do so, only when the Turkish Cypriot 'representatives' have dropped their institutional titles; or, dropping de jure the state's recognition. Turkish Cypriot interviewees suggest that their formal institutions forbid, by law, any contact with the Greek Cypriot institutions that would eventually lead to genuine rapprochement. Instead, they argue that their formal institutions selectively choose those contacts that would result in indirect recognition of the Turkish Cypriot constitution.

Similarly, Greek Cypriot formal institutions have been alarmed, when Turkish Cypriot 'representatives' are directly contacted. The UN-sponsored funding procedure elaborates on this statement. Greek Cypriot formal institutions have had the 'right' to receive, and deliver, the assigned funds to the Greek Cypriot Municipality (Interview, senior UNOPS employee). It is added, the Turkish Cypriot Municipality would be then able to contact the Cyprus Red Cross Society, which has the duty of delivering the destined funds. As such, the funding procedure appears problematic, largely due to the issues of not recognition.

Analysis of this study suggests two-contradictory arguments. One concerns the formal institutions that are on their own unsuccessful in mobilizing any degree of urban development. The local actors (former mayors) are paramount in this vein who have spotted a 'neutral' political space at the local level, contributing to a significant change in a period marked by a deadlock of political negotiations, as they have adopted negotiation skills so as to convince the formal institutions on either side not to hinder the joint projects (see next sub-suction on the role of plans and planners).

The other argument concerns only when formal institutions accept a joint initiative with the 'other side', any degree of development is possible. Each side's formal institution has expected economic improvements from the NMP due to the deficiencies witnessed in each side's socioeconomic conditions. The expectation has encouraged both sides' formal institutions to accept the NMP. The assumption is that economic boost on either side through urban projects has strengthen the argument for the NMP. Besides, Turkish Cypriot formal institutions conceive the NMP as a tool to legitimate a 'separate co-existence', whereas the Greek Cypriots view the NMP as a tool to achieve 'unification'.

At the official handing ceremony, January 1985, the former Greek Cypriot mayor considers the completion of NMP's Phase I as a 'landmark in the tormented life of our capital city' [41]. This is because the NMP has recognized the political nature of planning, giving enough time to explore what Cypriot 'representatives' value, or what they had in common. As a Greek Cypriot interviewee (architect and former NMP member) explains: 'It's been a wise process in that we've begun with collecting data'. A Turkish Cypriot interviewee (planner and former NMP 'team leader') adds, the attitude of Cypriot 'representatives' has been 'let's talk about what we value and what we are concerned about [... let's get the horse before the cart'.

Throughout Phase II, a slow process has been witnessed where informal institutions have been transformed into 'dead institutions' [21], largely due to context. Interviewees' accounts explain that the initial focus has been on 'what to do with the area schemes', rather than on the nature and roots of the key issues at hand. Unlike Phase I, as interviewees report, Phase II has ignored 'what participants had in common', or 'what participants valued'. Instead, the concern has been with 'planning'. The 'representatives' have been overwhelmed with the interests of the former mayors, to proceed with a sense of emergency and mission, leaving aside values and interests of others. As a Turkish Cypriot interviewee (architects and former NMP member) suggests:"[thinking] there were NMP members who were disappointed because the outcomes did not match their expectations. And I believe they will see that there was no necessity for participation"

\subsubsection{The Role of Plans and Planners}

The concern, here, is with formalization through formal/informal dialectics. Actors are paramount in this respect. Those interviewed for this study have, without hesitation, pointed to the former mayors. Interviewees have had the belief that former mayors have initiated the NMP. It is worth pausing briefly to explain the former mayors' involvement.

Their initial start has been in 1979 to re-connect the sewerage systems, existed on either side of the UN Buffer Zone. Unfortunately, the UN-funded sewerage project had been ceased in 1974 war on Cyprus. Despite both Cypriot communities' traumatic memories the former mayors have succeeded in 1978 in re-connecting certain units, as they have worked together without attracting much media attention [42]. Such style of work has helped them to defuse both Cypriot communities' fears because each community has grasped the benefit of joint projects.

What inspire the former mayors to take on the troubles in re-connecting the sewerage systems lies in their shared interest that has been crucial for not only re-connecting the sewerage units but also for revitalizing historic Nicosia:

"The sewerage system [...] led us to the Master Plan [...] once we achieved certain progress and both sides saw the fruits of co-operation, we [former mayors] should further this cooperation" (The Cyprus Weekly Magazine, no. one, November 1989:13).

The former mayors, inspired by their shared interest, embody a strategic context, where the way to formalize an institution (the NMP) runs in accord to adopting plans as tools in 'power games'. In Nicosia's context, formal institutions of both sides have not been 'politically neutral'. Rather, they have been equipped with strategic interests, striving for private investments when starting the NMP.

What mobilize formal institution's interest in the NMP are their expectations to improve their side's economy. Turkish 
Cypriot formal institutions have sought ever since equal share of the UN funds with their Cypriot counterpart. This is because the UN funds have been allocated according to population ratios of 1947- namely $80 \%$ for Greek Cypriots and, only, $18 \%$ for Turkish Cypriots [43]. For the Greek Cypriot formal institutions, to implement the area schemes of the NMP, existed within their Central Area, the public investments needed are 'twice' as that already being invested in the entirely NMP's area [44]. New formality, the NMP, emerges due to the discrepancies observed in each formal institution's interest.

This discrepancies note how the 'paper plans' are interpreted within a particular context. The NMP has fallen into a dispute fuelled from interests of each side's formal institutions, which are inherited from political goals. For the Greek Cypriots, the NMP represents breaking down the UN buffer zone, thereby institutionalizing the possibility of reunification (Interview, former Greek Cypriot mayor). By contrast, for the Turkish Cypriots, the NMP demonstrates their hope to recognize their constitution based on a satisfactory 'status quo' [45].

The contradictory interests of both side's formal institutions have overshadowed the NMP, transforming the latter's objectives:

"the joint discussion crystallized in its process a political tension between Greek Cypriot participants who were for one team and supported proposals for one city, and Turkish Cypriot participants who were in favor of two NMP teams and two NMP proposals [...] And so there was a consciousness of this as a political process" (Interview, a Greek Cypriot planner and former 'representative')

The NMP has thus 'mirrored a political fight of the bigger picture [...] And so the joint plan [...] is now more political, rather than apolitical' (Interview, a Greek Cypriot architect and current 'representative').

Formal institutions of both sides have formalized the NMP by suppressing its discourses. A Greek Cypriot planner and former 'team leader' has revealed:

"The NNP team in the south is now part of a larger cake [formal institutions], which has other priorities than the NMP team. The institutionalization process [formalizing the NMP] has assimilated the team by absorbing it in its institutional hierarchy"

Or, the method adopted in Nicosia case to formalize informality appears to be 'absorbing' the NMP into each institution. The method incorporates the NMP in each side's institutional hierarchy; however, it shows denial of recognizing it as an independent entity. Most Greek Cypriot interviewees have reported that their side's 'representatives' have had to consult their Municipality on issues raised within the NMP discourses. A Greek Cypriot interviewee, a sociologist and current 'representative', has further suggested that Greek they have had to await approvals of the Municipality.

'Absorbing' into, or suppressing informality to formalize it, becomes the ensure formalization predominates in the planning legislation. On the Greek Cypriot side, despite the
Planning Law of 1990 adopting the NMP as the basis to draft the Nicosia Local Plan the role of the NMP has not been yet defined [40]. The NMP has not yet had any degree of autonomy. Nor did this plan possess any statutory authority. This is because:

"[...] Town Planning and Housing Department gives a professional advice on drafting the local plan in the Common Board meetings [...] applications are more likely to be refused if these are not in line with the department's points of view" (a Greek Cypriot interviewee, architect and former 'representative')

'Absorbing' into can also affect the exercise of discretion (the freedom to make a choice within a discourse without manipulation) in relation to the decisions reached at the NMP discourses. A Greek Cypriot interviewee, sociologist and current 'representative', has in response commented:

"[...] the bi-communal projects of the NMP have to be revised and reviewed by both the Municipality of Nicosia and the Town Planning Department, with the consequence of more delays in completing the projects"

Not surprisingly, therefore, Greek Cypriot interviewees advocate the argument that their formal institutions have 'institutionalized power' to ratify the NMP through their formal institutions' right to 'accept and/or reject' whatever decisions reached at the NMP.

For the Greek Cypriots, suppressing the NMP has been a necessity because of the threats it poses. The UN-sponsored funding procedure is a good example. Greek Cypriot formal institutions have been alarmed, when the UN agencies 'directly' contact the Turkish Cypriot 'representatives'. This is because the Greek Cypriot side fears 'de jure' recognition. In essence, Greek Cypriots fear de facto extension of the UN territories, thereby contraction of the Greek Cypriot's sovereignty (The Cyprus Weekly newspaper, 13-19/2/87).

The fears of 'de jure' recognition; fuelling distrust with the consequence of suppressing the NMP, has arguably laid the template for the Greek Cypriot institutions not only to pose legitimate actions but surprisingly to accept their side's 'representatives' collaborating with the Turkish Cypriots over technical projects (The Cyprus Weekly, 25/6-1/7/93).

Suppressing the NMP has been also a necessity for the Turkish Cypriots. Turkish Cypriot interviewees have supported this argument because their formal institutions acquire legitimate actions over the NMP. Their side's 'representatives' have been wrapped up in a 'matrix' of institutional hierarchy, pulling the NMP into varied interests. Turkish Cypriot interviewees have offered two examples to illustrate this. They have pointed to a conflict between their Municipality and Town Planning Department, on their side, in 1990, largely due to the former accumulating power by arguing that it has been its right to issue building permits. A second example concerns co-existence with the Greek Cypriots by means of two-separate entities which would hinder a shared form of decision-making. To do so, their Municipality has employed dozens of Turkish Cypriot 'representatives' since 1990 (Interview, Akinci, former Turkish Cypriot mayor). The aim has been to influence the 
decisions reached at the NMP through Turkish Cypriot employees/'representatives' having 'fear' to lose their jobs, when they jeopardize their Municipality's policy of coexistence (Interview, Turkish Cypriot planner, former NMP 'team leader'). A formalization process has followed navigating the NMP in two opposing directions.

The perspective of formal/informal dialectics suggests three scenarios to the functioning of new formality [21]. The first concerns a 'fragile trust'. This occurs in Nicosia case. Difficulties in generating trust among the 'representatives' have been evident. No wonder that some 'representatives' have had questioned their participation in the NMP:

"[...] I must tell you that there was much mistrust of and doubt about the other side, particularly at the beginning in early 1980s. When we started the discussion with the other side, honestly I was asking myself what do these Greeks want from us" (Turkish Cypriot interviewee, planner and former leader of the NMP team)

A second scenario concerns a reproduction of the already established power structure [21]. Interviewees' account supports the assumption that institutional and political legacies have stepped into the NMP transforming its discourses to a new 'story-line', derived from the strategic goals of both formal institutions - Greek Cypriots for unifying the Cypriot Island, whilst Turkish Cypriots for a 'status quo'. This lays the template for the NMP to draw into other priorities. As a result, "both sides implement their bicommunal projects independently without much discussion occurring between the two" (Head of the Turkish Cypriot Town Planning Department and former 'representative')

A third scenario [21] concerns new formality that functions as a "façade". This scenario occurs in Nicosia case. Analysis in this study suggests that the Greek Cypriot formal institutions have sought through the NMP to stem depopulation of the Nicosia's boarders and to revive its Walled City's function as a center (The Cyprus Weekly, 25/61/7/93). The NMP, for the Greek Cypriot formal institutions, represents breaking down the UN Buffer Zone and lays the template for reunification (If not Cyprus, at least of Nicosia) (Interview, former Greek Cypriot mayor). For the Turkish Cypriot formal institutions, the NMP presents their hope to recognize their constitution that by adopting a 'step-by-step' approach on the 'smallest issues' [46], such as technical projects, it would be possible to achieve with minimal friction a satisfactory 'status quo'. The UN agencies have also used the NMP as a 'façade' of proceeding quickly with physical planning [47], thereby surmounting some aspects of the divide by adopting a development strategy of pursuing 'unification goals' [48].

\subsubsection{Participation or Inclusiveness}

As analysis in this study suggests, Greek Cypriot and Turkish Cypriot 'representatives' have been able at some stages to reconcile their technical knowledge, thereby celebrating a comprehensive plan in 1984, whilst at other stages this was impossible. This is because the "participatory structure' [21] is each time reinterpreted that its consequences are invisible to participants, supporting the assumption that it is hard to predict how the new formality proceeds.

Indeed, despite the 'representatives' entering the discourses in their capacity as professionals, suggesting that the discourses could be abstracted from their institutional and legal legacies, interviewees for this study suggest that the political context of other settings has been woven into the process. As a result, some 'representatives' have had misgivings about the outcome of joint planning. Others have had troubles in trusting the 'other side': ' I did not feel safe enough that if I say something the others were going to respect it, as it might look silly' (Interview, Turkish Cypriot architect and former NMP member).

Interviewees' accounts blame the UN consultants for involving strategically because their engagement ensures understanding of the technical matters while narrowing the focus of concern to the 'representatives' on consolation. For example, the UNDP has employed around forty consultants, who have enabled a discourse in which claims for attention could 'be heard', respected and valued (interview, Greek Cypriot planner and former NMP member). This example shows the UN consultants reinforcing a purely technical discourse. Indeed, the consultants have not been 'fighting battles which have been already won' (Interview, Turkish Cypriot planner and NMP member).

In a later stage of Phase I, a policy to revitalize Nicosia has been celebrated. A fourth scenario emerges to the functioning of new formality. A change has come about and informal institutions have evolved differently, since Phase II. The change witnesses the formal institutions of both sides becoming much involved in area schemes' rehabilitation than in Phase I, thereby forging a number of strategic actions to transform the NMP to a new 'story line'. For example, Greek Cypriot interviewees shed light on the public authority's promise of overruling planning controls to achieve consolidation (see also The Cyprus Weekly, 25 June 19931July 1993). Or, Greek Cypriot 'representatives' advocate their formal institutions' initiatives. Nevertheless, the Greek Cypriot's view has been impractical due to ignoring the inflation in Turkish Cypriot territories which not only derives the cause for economic disparity with the Greek Cypriot territories [44], but also represents an obstacle to the use of internal source of finance. Economic imperatives, arising as a result of strategic interest, are maintained.

Another example is a conflict of interest among Cypriot 'representatives'. The UNHCR's funds are organized following population ratios of 80 per cent (Greek Cypriots) and 18 per cent (Turkish Cypriots). Turkish Cypriot 'representatives' have strived for 50:50 shares of NMP funds because they consider the ratio as 'unfair'. The 'representatives' are unlikely to exclude their concerns, and have entered the discourses strategically.

\subsubsection{The Role of Organization}

The formal institutions existed on either side of the UN Buffer Zone fuel their contest from a sovereign dispute 
overwhelmed by a continuous struggle over the legitimacy of each constitution. The Nicosia case, analyzed here, shows the Turkish Cypriots having inequality with the Greek Cypriots, as a dominant group. Organizations of either side are devoted to safeguard their common belonging and call for separate identities. The analysis illustrated previously in this section has shown numerous examples, where two-conflicting universes remain posing a threat to any shared form of coexistence.

In particular, the 'representatives' employed in various Greek Cypriot institutions, and interviewed for this study, have emphasized a good level of collaboration with the Turkish Cypriots 'representatives', when asking while being interviewed 'how different participants were in their claims at achieving their objectives'. Those, by contrast, who have joined the NMP in the past and currently are employed by the private sector, have highlighted some disagreements that have overshadowed the NMP discourses. The varied responses suggest that the Greek Cypriot formal institutions have an impact on their employee, who might have fear to object the dominant politics of their belonging institutions, which encourage collaboration with the 'other side' to realize their hope for unifying the Island.

Conversely, Turkish Cypriot 'representatives' answered without hesitation to the same question. They have revealed that there have been disagreements between Greek Cypriot and Turkish Cypriot 'representatives', particularly when implementing the areas schemes. Turkish Cypriot 'representatives' have less emphasized the importance of collaboration over joint projects with Greek Cypriots. While being interviewed Turkish Cypriot 'representatives' are reluctant to participate in the interview schedule for this study once knowing that their Departments' heads have not been approached yet for an interview. It appears that Turkish Cypriots have also fear to oppose the dominant politics of their institutions, which are in favor of a satisfactory 'status quo'.

The above differences, the author did not expect but has faced while undertaking the empirical investigation, highlight re-interpretation of institutions situated within different organizations. Such interpretations are not 'predictable' [21], with the consequence of contrasting effects that might lead to smooth or vague coordination. The Nicosia case shows that the NMP has stepped into both sides' dispute over territories despite attempts being made to ensure that the 'representatives' have a 'voice' or 'route to voice'. Surprisingly, a consensus has emerged at a later stage of Phase I. A change continues to occur. Phase II shows a slow process of implementing the area schemes. What derives such a change has been explained in previous subsections.

\section{Conclusions}

The foregoing discussion, concerned with how formal and informal institutions interact in planning, has put forward several arguments. One argument concerns a 'mutual shaping' that has been evident in the Nicosia case and points to the deficiencies of largely depending on formal institutions [see, 16-23]. How informal institutions have their effects or shape the interaction? Crucial has been the role played by the local actors [17-18]. Their 'bargaining skill' introduces them as 'new' actors operating at the municipal level to mobilize planning. Other strategies, evident in analysis of this study, note the local actors adopting a style of working 'sincerely' in an attempt to avoid planning becoming involved in issues of political circumstances [see, 17-20]. Collectively, the strategies have been convenient for the formal institutions not to circumscribe the effort of local actors and are considered as an essential step to be undertaken (see also, [39]). This is because, as analysis in this study suggests, only when each side's formal institution has accepted informal actions, planning at the local level is permitted.

What are the effects of formal institutions [11, 14] and how these shape the interaction occurred. In response, as analysis in this study suggests, local actors on their own are insufficient and their effort would not obviate the central role of formal institutions. What is perhaps notable is how the formal institutions remained, as a token, playing a central role if not the key determinant. Formal institutions have remained 'dead institutions' [21] in the Nicosia case, largely because these are blocked from mobilizing planning at the local level and remarkably these blocks have been found in the Nicosia case to have played a role in hindering and/or accepting the planning process of the NMP, namely though the lens of exercising legitimacy over the NMP's planning.

Another argument concerns what mobilizes a 'mutual shaping' perspective. Analysis situated within the Nicosia case supports in this respect the perspective of formal/informal dialectics [21], that is, both a 'continuous interpretation' and unpredictability underpin the view of a 'mutual shaping'. The formal institutions have been weighing up their benefits of the NMP in relation to municipal revenues and expected economic improvements, represented in evaluating how important planning has been in association with the economic gain/loss. Each side's formal institution has interpreted the NMP differently leading to accept planning with the 'other side'. Another example is the issue of recognition, questioning the legitimate status of the NMP and slowing down its progress. Contrasting interpretations follow where Turkish Cypriot formal institutions conceive the NMP as a tool to legitimize the 'separate co-existence', whereas the Greek Cypriot formal institutions view the NMP as a tool to fulfill their hope to 'unification'.

The different interpretations draw on a context ([19, 20, $22,23,24])$ in which planning is situated at the local level and which embodies power relations marked by strategic actions that shape the interaction of formal and informal institutions. Van Assche et al. [20] acknowledge the notion of context; however, their analyses turn to 'metarules', the swap of rules and roles. This has not been the case in Nicosia analysis. Instead, the latter analysis highlights the importance of context marked by power relations as the key to address how the dialectics of formal/informal institutions occur.

A further argument concerns formalization [21]. The 
Nicosia case offers two examples in this respect. Firstly, the formal institutions enforce a number of methods emerged as a result of not recognizing 'the other'. The second example draws on the dominant politics of the formal institutions which have been woven into the NMP discourses transforming its planning. Decisions reached have been on the basis of consultation with the formal institutions. The method adopted in the Nicosia case to formalize informal institutions is that the formal institutions have 'absorbed' the NMP into each institutional hierarchy making use of planning law as a method and the 'representatives' have been 'clothed' in the interest of each side's institution. As analysis of this study has shown, the extent to which formal institutions have been able to ratify the NMP has been key to how the 'representatives' have handled the issues discussed within the NMP discourses. The formal institutions have besides denied a separate entity of the informal. The NMP has not yet had any degree of autonomy. Nor did this plan possesses any statutory authority.

It is assumed that it is difficult to predict how a new formality functions [21] and accordingly three scenarios are on the table. All three scenarios have been evident in the Nicosia case which draw on the notion of strategic actions. The Nicosia case adds a fourth scenario (a consensus). The predictabilities to the functioning of new formality could be positive, too; not merely negative. Here in Nicosia case, this positive predictability is about celebrating a consensus, or about a reproduction of a 'participatory structure' [21] that is used as a 'façade'. Thus, the everyday politics have been found in the Nicosia case to be not only driven by strategic actions [21], but also by a consensus.

\section{References}

[1] Bolan R (1991): 'Planning and institutional design', Planning Theory, Vol. 5, pp. 6 7-34.

[2] Gualini E (2002): "Institutional capacity building as an issue of collective action and institutionalisation: some theoretical remarks", in Institutional Capacity Building as an Issue of Collective Action and Institutionalisation: Some Theoretical Remarks Eds G Cars, P Healey, A Madanipour, C de Magalhaes (Ashgate, Aldershot, Hants) pp. 29 -44.

[3] Healey P, Cars G, Madanipour A, de Magalhaes C (2002): "Transforming governance, institutionalist analysis and institutional capacity", in Transforming Governance, Institutionalist Analysis and Institutional Capacity Eds. G Cars, P Healey, A Madanipour, C de Magalhaes (Ashgate, Aldershot, Hants) pp. $6-28$.

[4] Alexander E R (2000): "Inter-organizational coordination and strategic planning: the architecture of institutional design", in Inter-organizational Coordination and Strategic Planning: The Architecture of Institutional Design Eds. W Salet, A Faludi (Royal Netherlands Academy of Arts and Sciences, Amsterdam) pp. 159-174.

[5] Healey P, 1998, "Building institutional capacity through collaborative approaches to urban planning" Environment and Planning A, Vol. 30, pp. 1531 - 1546.
[6] Mahoney J and Thelen K (2010): 'A theory of gradual institutional change', in J. Mahoney and K. Thelen (eds), 137.

[7] Waylen G (2014): "Informal institutions, institutional change, and Gender equality, Political Research Quarterly, Vol. 67(1), pp. 212-223.

[8] Hall V and Taylor R (1996): 'Political science and the three new institutionalisms', Political Studies, 44, 936-57.

[9] Hay C (2008): 'Constructivist institutionalism', in R. A. W. Rhodes, S. A. Binder and B. A. Rockman (eds), The Oxford Handbook of Political Institutions, New York, NY, Oxford University Press, 56-74.

[10] Pontusson J (2005): Inequality and Prosperity: Social Europe vs. Liberal America, Ithaca, NY: Cornell University Press.

[11] North D (2001): Needed: A theory of change in Meir, G. M. \& Steigler, J. E., Eds. Frontiers of development economics: The future in perspective, Oxford, Oxford University Press: 491.

[12] Rizzello S and Turvani M (2002): Subjective diversity and social learning: a cognitive perspective for understanding institutional behaviour in Constitutional Political Economy, Vol 13, pp. 197-210.

[13] Williamson E (2000): The new institutional economics: Taking stock, looking ahead in Journal of Economic Literature, Vol. 38(3), pp. 595-613.

[14] North D (1990): Institutions, Institutional Change and Economic Performance, New York, NY, Cambridge.

[15] Lowndes V and David R (2013): Why Institutions Matter, Basingstoke: Palgrave.

[16] Radnitz S (2011): "Informal Politics and the State", Comparative Politics, Vol. 43 (3): pp. 351-71.

[17] Helmke G and Levitsky S (2004): "Informal Institutions and Comparative Politics: A Research genda", Perspectives on Politics, Vol. 2 (4): pp. 725-40.

[18] Helmke G and Levitsky S (2006): "Introduction.” In Informal Institutions and Democracy: Lessons from atin America, edited by Gretchen Helmke and Steven Levitsky, 1-32, Baltimore: Johns Hopkins University Press.

[19] Azari J and Smith J (2012): "Unwritten Rules: Informal Institutions in Established Democracies." Perspectives on Politics, Vol. 10 (1): pp. 37-55.

[20] Grzymala-Busse A (2010): The best laid plans. The impact of informal rules on formal institutions in transitional regimes., Studies in Comparative International Development, Vol. 45, pp. 311-333.

[21] Van Assche K, Beunen R, Duuineveld M (2014): 'Formal/informal dialectics and the self-transformation of spatial planning systems', Administration and Society, Vol. 46 (6), pp. 654-683.

[22] Tsai, Kellee. 2006. "Adaptive Informal Institutions and Endogenous Institutional Change in China", World Politics Vol. 59 (1): pp. 116-41.

[23] Williams, $\mathrm{N}$ and Vorely, $\mathrm{T}$ (2015): Institutional asymmetry: How formal and informal institutions affect entrepreneurship in Bulgaria, International Small Business Journal, Vol. 33 (8), 840-861. 
[24] Salet M (1994): Om Recht en Staat (On law and state). The Hague, the Netherlands: WRR (Netherlands Scientific Council for Government Policy).

[25] Giddens A (1984): The constitution of society, Cambridge, UK: Polity.

[26] Kiser J and E Ostrom (1982): The three worlds of action. In Strategies of political enquiry, edited by E. Ostrom, 179-222. Beverly Hills, CA: Sage.

[27] Weber M (1921): Economy and Society: An Outline of Interpretive Sociology, Berkeley, University of California Press, Vol. 2, 1978.

[28] Ostrom E (1990): Governing the commons, Cambridge, UK Cambridge University Press.

[29] High C, Pelling M and Rengasamy S: (2004): Local agency, adaptation and the shadow system: The institutional architecture of social learning in rural areas of the UK and India. XI World Congress of Rural Sociology, Trondheim, Norway.

[30] North D. (1997), 'Understanding Economic Change', in J. Nelson, C. Tilly, L. Walker, eds., Transforming Postcommunist Political Economies, Washington D. C., National Academy Press, 13-18.

[31] North D (1994): 'Economic Performance Through Time', American Economic Review, 84(3), June, 359-368.

[32] Pejovich S (1999): "The Effects of the International of Formal and Informal Institutions on Social Stability and Economic Development", Journal of Markets \& Morality, Vol. 2 (2): pp.164-81.

[33] Winiecki J (2000): 'Formal Rules, Informal Rules, and Economic Performance', Acta OEconomica, Vol. 51(2), pp. 147-172.

[34] Nee V (1998): 'Norms and Networks in Economic and Organizational Performance', American Economic review, Vol. 88 (2), May, pp. 85-89.

[35] Voigt S and Engerer H (2001): 'Institutions and Transition. Possible Policy Implications of the New Institutional Economics', SSRN, Working paper, December.
[36] Lutzoni, L (2016): "Informalized urban space design: rethinking the relationship between formal and informal, City, Territory and Architecture, Vol. 3 (20), pp. 1-14.

[37] Levitsky S and Slater D (2011): "Ruling Politics: The Formal and Informal Foundations of Institutional Reform", Paper, Workshop on Informal Institutions, Harvard University, Cambridge, MA.

[38] Hegel F (2011): Nauka logiki [Logics science] t.I, Warszawa: PWN.

[39] Cozzolino, S (2017): The City as action: the dialectic between rules and spontaneity, Polytechnic University of Milan, Department of Architecture and Urban Studies, Unpublished $\mathrm{PhD}$ Thesis, Milan, Italy.

[40] UNDP/UNCHS (Habitat) (1984): Nicosia Master Plan: Final Report, Nicosia (south): UNDP/UNCHS (Habitat).

[41] UNCHS (Habitat) (1988): Nicosia Master Plan: A landmark for Future Cyprus, Nairobi: UNCHS.

[42] Demetriades L (1998): 'The Nicosia Master Plan', Journal of Mediterranean Studies, Vol. 8 (2), pp. 169-176.

[43] UNHCR (1996): The Nicosia Sewerage Project: A plan for Nicosia A strategy for the World, UNCHR: Nicosia (south).

[44] UNDP/UNCHS (Habitat) (1985): Nicosia Central Area, Vol. VIII, Investment programme, Nicosia (south).

[45] Mitchell J (1983): 'Case and institutional analysis', Sociological Review, Vol. 31 (2), pp. 186-211.

[46] Hocknell P (2001): Boundaries of Collaboration: Cyprus, de facto Partition, and the Delimitation of Transboundary Resource Management, Boston: Kluwer Law International.

[47] UNDP/UNCHS (Habitat) (1981): Nicosia Master Plan C.B.D. (Central Business District) - Analysis of Existing Situation, Nicosia (south): UNDP/UNCHS (Habitat).

[48] UNDP (1991): UNDP in Cyprus: 1960-1990, Nicosia (south): UNDP office. 